\title{
Aliens' Arrival and the End of the World - An Apocalyptic Reading of Childhood's End
}

\author{
Kamelia Talebian Sedehi \\ Faculty of Modern Languages and Communication, Universiti Putra Malaysia, Malaysia \\ Hardev Kaur \\ Faculty of Modern Languages and Communication, Universiti Putra Malaysia, Malaysia
}

\begin{abstract}
Science fiction is a literary genre which provides the ground for scientific discoveries. One of the subgenres of science fiction is apocalyptic literature, which deals with the end of the world. Arthur C. Clarke is considered one of these apocalyptic writers whose Childhood's End indicates an alien invasion and the outcome of their interference with the affairs of human beings. This article intends to emphasize the apocalyptic elements within Childhood's End and, further, it will highlight how the writer uses this genre in order to deal with the delineation of religion and science, the mutation of children and the destruction of Earth.
\end{abstract}

Index Terms—apocalyptic literature, Aliens' invasion, Arthur C. Clarke, Childhood's End

\section{INTRODUCTION}

Science fiction is a fantastic genre that remains important today, one that makes claims for the plausibility of science. In fact, science fiction literature is work turned into fact, as some writers wrote about something imaginary in their novels and scientists later made the same thing which was once considered to be an imaginary object. One can consider Plato's Republic as the first utopian science-fiction literature book. Later, 1984, Frankenstein and Brave New World have been considered as science fiction; these depict government surveillance, uncontrolled technology and space weaponry. Displacement is one of the characteristics of science fiction and one can notice displacement in place, time and social conditions. Displacement offers the possibility of perspective, irony and the fantastic.

One of the subgenres of science fiction is apocalyptic literature. In 1822, the term "apocalypse", as a new genre, was coined by a German scholar, K. I. Nitzsch. However, later on, "the first critic who attempted to identify its conventions was Friedrich Lücke, who published a study of apocalyptic literature in 1832. The attempt to identify the conventions of apocalypse continues until this day" (Linton, 2006, p. 33) and the word apocalypse means revelation; it refers to a religious background, however many novelists use this term these days to express causes which may lead to the end of the world. In Greek, apocalypse means "revelation", but generally speaking it refers to the final book of the Bible, the Revelation of John. In literature,

[A] pocalypse is a genre of revelatory literature with a narrative framework, in which a revelation is mediated by an otherworldly being to a human recipient, disclosing a transcendent reality which is both temporal, insofar as it envisages eschatological salvation, and spatial insofar as it involves another, supernatural world. (Lewis, 2004, p. 17)

Based on apocalyptic novelists' imagination, the world is shown as ending with greenhouse effects, extra-terrestrial invasions, nuclear bombs and other technological progresses. Moreover, they focus on "the numerical models of climate change, and space guard program tracks, those asteroids in orbits that may possibly collide with earth" (Wells, 2009, p. 95). These apocalyptic novels deal with the ways people handle difficulties, face dangerous situations and are tormented as the result of a hard life. Critics "became sensitized to the apocalyptic elements in works not formally of type, but whose language, particularly imagery, touches on the themes of revelation, renovation and ending" (Childs and Fowler, 2005 , p. 9). Apocalyptic texts indicate the miseries men go through by portraying sores, wounds and scars. One can notice that, in apocalyptic novels, every one of the characters can be a victim of the end of the world; therefore, both angelic and devilish characters are doomed to die; there is no difference between them. As such, apocalyptic novels reflect common suffering. According to Frank Kermode, "apocalypse depends on a concord of [an] imaginatively recorded past and [an] imaginatively predicted future, achieved on behalf of us, who remain in the middlest" (2000, p. 8). One should notice that, in apocalyptic literature, predictions of past events are narrated as prophesies. The narrator uses symbolic language in order to talk about different events implicitly. The purpose of apocalyptic texts is not to show the end of the world as such but to depict the destruction of the world and the birth of a new Jerusalem. As a result, apocalypse leads to a better future.

\section{ANALYSIS}

Arthur C. Clarke is the best science fiction and apocalyptic writer who foresaw geostationary satellites which help people to hear news from all over the world. Clarke has a scientific imagination; he writes something based on his 
imagination, and later scientists invent the machine; and in his works he indicates the possibility of a settled utopia that humanity might attain. Clarke's Childhood's End is an apocalyptic novel in which aliens invade Earth. Human beings are going to destroy the earth in a nuclear war, but aliens interfere to prevent it and claim they have good cause. Even Stephen Hawking believes that "humankind will extinguish itself from the face of the planet through the misuse of the biological weapon" (Joseph, 2007, p. 3). In addition, one can consider the nuclear threat as the single greatest immediate peril that threatens mankind (Daley, 2010, p. 38). However, one notices that the aliens' interference and invasion lead to the disappearance of the human race and the emergence of a post-human body; the human race combines with these aliens and is transformed into senseless emotionless creatures. In Clarke's Childhood's End, overlords believe that the new Jerusalem will happen when the human race disappears from the face of the earth; however, they do not reveal their intention when they land on Earth. As such, this article intends to delve into the apocalyptic elements which are used in this novel to indicate man's disappearance from the earth. Before analyzing the story, a short summary of the plot can help the reader to perceive the main points of this paper.

Aliens land on Earth and they call themselves supervisors and overlords whose intention in landing is to avoid human extinction. They claim that they will not interfere in human affairs. One of the supervisors is Karellen, who is assigned to be the supervisor of Earth; he informs Stormgren, the UN secretary general, that he and other supervisors will reveal themselves to humans within 50 years. After 50 years, the overlords show themselves to humans and they are like the images of demons. These overlords are interested in psychic research. One of the families in whom the overlords are interested is the Greggsons, especially their children, Jeffrey and Jennifer Anne. Once, the overlords saved Jeffrey's life when a tsunami engulfed an island. Sixty years later, with the aliens' first arrival on Earth, Karellen reveals their purpose in landing on Earth which is to serve the overmind, the vast cosmic intelligence. The aim of the overlords is to merge humans and the overmind. Therefore, human children do not show any signs of humanity as a result of these supervisors' interference; human children communicate through telepathy and are turned into transhumans. As such, unlike the supervisors' first claim, the humans become extinct. Now that the reader knows a little about the story, an analysis is conducted in the rest of the paper.

As the novel opens, the end of the first chapter announces the aliens' arrival on Earth implicitly by stating that the "human race was no longer alone" (Clarke, 1987, p. 12). As the aliens arrive, they claim that their intention is to help humans have unity and befriend each other. They have realized that, through wars and enmity, "humanity will have lost its initiative and become a subject race" (Clarke, 1987, p. 17). The aliens call themselves overlords and they are worried about the end of the humanity, as people do not care about each other but focus only on their own welfare. One notices that by embracing the elements of science fiction, the apocalyptic narrative deals with visions of future events. Although it talks about the future, it focuses on some aspects of the present, "these fictions act as an ideological diagnosis for the present day" (Grossman, 2011, p. 11). In this novel, the narrator pays attention to atomic bombs and wars between countries which may lead to the disappearance of human beings from Earth. The aliens have complicated technology, as "there had been no warning when the great ships came pouring out of the unknown depth of space" (Clarke, 1987, p. 17). There was no warning as no one perceived their impending arrival. They came mysteriously. People never believed in extra-terrestrial beings, although they had seen movies about them. "Now it had dawned at last; the gleaming, silent shapes hanging over every land were the symbol of science man could not hope to match for centuries" (Clarke, 1987, p. 17). They have high-tech instruments with them and humans cannot compete with their technologies; even if centuries pass, humans cannot have the same instruments that these aliens use when they arrive on Earth. "Master psychologists were studying humanity's reactions" (Clarke, 1987, p. 17), through knowledge about men's reactions; these master psychologists can predict people's reactions to them and the way they can prevent any kind of clash between themselves and the people.

The aliens consider themselves as a guide to human beings. "And on the sixth day, Karellen, Supervisor for Earth, made himself known to the world in a broadcast that blanketed every radio frequency" (Clarke, 1987, p. 18). They believe that humans are destroying themselves and the earth; therefore, it is their duty to lead humans in the right path and they call themselves supervisors, which is a symbol of the knowledge they have. As a result, they are deemed appropriate to guide mankind. They even speak the English language very fluently in order to let all humans understand their words. It indicates how intelligent and informed they are about humans. "It was a work of superlative genius, showing a complete and absolute mastery of human affairs" (Clarke, 1987, p. 18). Humans' knowledge and reason are questioned here as aliens are portrayed as intelligent and geniuses. As a result of their intelligence, the aliens can control men. "There could be no doubt that its scholarship and virtuosity, its tantalizing glimpses of knowledge still untapped were deliberately designed to convince mankind that it was in the presence of overwhelming intellectual power" (Clarke, 1987, p. 18). The supervisors intend to persuade mankind that they are wiser than the human race; as a result, humans should be obedient and listen to them to have a better future: the utopia that these supervisors intend to provide for the future of human beings. "In fact, ['apocalypse' is] intended to interpret present, earthly circumstance in light of the supernatural world and of the future" (Webb, 1990, p. 125) and the presence of the overlords on Earth reflects how the future will be when the humans cannot trust their reason and their technology; therefore, they need to get help from outsiders.

Most of the people are convinced that these aliens have come for the sake of humans, in order to improve their future; therefore, they do not doubt the aliens' mission, in fact they needed help from otherworldly beings in order to feel 
secure (Helm, 2009, p. 8). In this apocalyptic world, aliens arrive and intend to ameliorate humans' situation, and the authenticity of religion is questioned. "Science can destroy religion by ignoring it as well as by disproving its tenets" (Clarke, 1987, p. 22). The more science progresses, the more religion comes under question. As a result, men cannot rely on religion and its instructions to gain salvation or a have better future, they only can rely on these aliens who are more intelligent and have more advanced technologies. In order to achieve their goal of providing a better future for humans, the overlords' first mission is to unify different nations. If, in the past, rich and knowledgeable men were called as lords, these aliens are called overlords to indicate their upper hand and superior knowledge. As the overlords' weapons are more advanced than those of the humans, the latter prefer to befriend them rather than fight and have wars with each other. "The greatest single obstacle to the happiness of mankind had been removed" through the help of aliens (Clarke, 1987, p. 25). The obstacle was the weapons that different nations used against each other. In addition, the aliens asked for fair government in each nation; no matter who rules and what their policies, the government should be fair and without any oppression or corruption. By ordering all these things and trying to unify humans, they question humans' reason, as for all these years people could not manage to unify nations even though they had made so much progress.

Unlike human beings' idea that only Earth has inhabitants, the overlords inform them that, "your world is not the only planet we've supervised" (Clarke, 1987, p. 53). These overlords rule everywhere, and to men's surprise other creatures live on other planets. "There have been legends suggesting that Earth has been visited in the past by other races. I know, I've read the Historical Research Section's report. It makes Earth look like the crossroads of the Universe" (Clarke, 1987, p. 53). Different extraterrestrial creatures have visited Earth and it is not surprising that this time it is the overlords' turn. In order to control humans, the overlords not only adopt the English language but also studied everything related to human beings and the earth before their arrival, which helps them to control men more easily. With knowledge, they rule. The supervisors inform men that they never tried to befriend each other, rather they always sought enmity using different weapons which destroy not onlyhumans but also the whole planet, and this will lead to the end of Earth in the near future; that is the main concern which leads aliens to visit Earth and arrange matters better.

As aforementioned, with the progress in science, religion is questioned; however, with the arrival of the overlords, humans are disheartened as they believe that there is no need to make any scientific progress given that the overlords know more than humans. Wojcik considers technological collapse to be one of the signs of apocalypse (1997, p. 99). Here the idea of science, as a way to live a better life, is rejected by humans. As a result, both religion and science have declined on Earth.

No Utopia can give satisfaction to everyone, all the time. As their material conditions improve, men raise their sights and become discontented with powers and possessions that once would have seemed beyond their wildest dreams. And even when the external world has granted all it can, there still remain the searchings of the mind and the longings of the heart. (Clarke, 1987, p. 90)

Even though humans have everything in their lives and live the dreamy life they once wished to have, they can never be satisfied as they are greedy to have more and more. Nothing can satisfy them, as wishing for more is part of human nature, which is the main reason why even the overlords' utopian world cannot satisfy men.

The overlords claim that they intend to save Earth and human beings by providing peace. People admit that "it is equally probable that we would have destroyed ourselves with cobalt bombs and the other global weapons the twentieth century was developing" (Clarke, 1987, p. 124). As a result, humans accept the overlords' dominance over them as they feel danger in their lives. "Probably the overlords have their reasons for keeping us in the nursery, and probably they are excellent reasons" (Clarke, 1987, p. 124). Humans doubt their own reason and intellect and believe that the overlords are more intelligent; therefore, they can decide more rationally. Besides, they think that they are not able to control their lives as they are not intelligent enough to improve their way of life.

Jan Rodricks intends to follow the overlords in order to perceive their true intention; therefore, he says goodbye to his family without being sure what will happen to them. This goodbye foreshadows the end of humanity. He says goodbye to all humans, as later on they will die.

The overlords assure the humans that they will be able to control the earth and the planet in the future. In fact, they question humans' reason when they handled everything, and so the humans can only follow their steps to have peace and an easy life. The overlords pretend that they are preparing the earth and humans for a forthcoming utopia, but "only Karellen knew with what inexorable swiftness the Golden Age was rushing to its close" (Clarke, 1987, p. 139). The overlords claim that the Golden Age will be achieved when men live in peace and pay attention to themselves and their planet; however, the overlords' real intention is to destroy human beings. One of the causes of the apocalypse in the future might be an "alien invasion" (Wells, 2009, p. 96).

Lateron, the reader perceives how Jeffrey's life is saved by the overlords as a flood rushes toward him. "Someone told me to run" (Clarke, 1987, p. 157). He was informed by the overlords to run when he could not decide what to do himself. The overlords helped him to escape, "close your eyes, Jeffrey, and put your hand in front of your face. It seemed a funny thing to do, but I tried. And then there was a great flash - I could feel it all over - and when I opened my eyes the rock was gone" (Clarke, 1987, p. 158). They moved a rock and let him escape the dangerous situation. Later on, Jeffrey's parents perceive that they are watched by the overlords and they are not alone at home. They notice 
that their son and daughter are not totally human, they have changed. The overlords change human children for the sake of their own plans. They are not normal children, they are mutants. The overlords accept that they brought "something new and wonderful into the world" (Clarke, 1987, p. 179). They intend to change the human race and they will take these mutant children with them, so they warn the parents "enjoy them while you may... they will not be yours for long" (Clarke, 1987, p. 180). They will separate these children from their parents for the sake of their experiment. Jeffrey's parents notice that their son has lost "his personality, dissolving hour by hour before their eyes" (Clarke, 1987, p. 183). There is an end to humanity, love and affection. These mutants are heartless and do not even care about their own parents, let alone other human beings."The world was numbed... it was as though the planet was in mourning lament all that now could never be" (Clarke, 1987, p. 183). Everything is mechanical and the planet mourns for the loss of humans, emotions and sentiments. As humans have lost their faith in everything, they should cling to something which can explain all the events and phenomena that happen each moment and everywhere, and science is the thing to which humans cling. "Science, it was felt, could explain everything there were no forces which did not come within its scope, no events for which it could not ultimately account" (Clarke, 1987, p. 186).

Human beings are going to become extinct. "All the hopes and dreams of your race are ended now" (Clarke 188). It is the end of humans and humanity. Based on David J. Leigh, one should consider the tensions within apocalyptic texts. He claims that one can notice the tensions between past and present, the spiritual and the corporal world (Leigh, 2008, p. 1-2). Here, the reader notices how human beings were powerful in the past and but have lost their power in the present as they belittled their own abilities. Moreover, the reader perceives how humans trust the overlords and in return their existence will cease. Besides Leigh, John G. Gammie discusses the matter of tension in apocalyptic texts and adds to Leigh's opinions. He defines ten different types of tensions: cosmic dualism, temporal/ eschatological, ethical, psychological, spatial, theological, physical, metaphysical, sociological and cosmological/ ontological (Gammie, 1974, pp. 357-359). Of all these ten tensions, two of them, temporal and ethical, are applicable here. Within temporal tension, one perceives a difference between past and present time, as mentioned before; and within ethical tension, one recognizes the tension between good and evil forces. In the beginning, humans considered the overlords to be their friends who came to guide them and save them; however, they show their true face later on by changing human beings into transhumans. "Nor would George ever know if Jeff had turned towards them by pure chance - or if he knew, in those last moments while he was still their son, that they stood watching him as he passed into the land that they could never enter" (Clarke, 1987, p. 192). The overlords take the children and their parents cannot follow them. In this place, the overlords put children under observation. "Homo sapiens was extinct" (Clarke, 1987, p. 212). Humans were supposed to be intelligent, but they question their reason and permit the overlords to decide for them that they are extinct. The earth is destroyed by the overlords as without humans the earth does not have any meaning. "There was nothing left on Earth" (Clarke, 1987, p. 212).

\section{CONCLUSION}

Contrary to other apocalyptic novels which describe the end of the world with images of terror, frustration and dystopia, this novel portrays a highly developed and prosperous utopia which ends in a cataclysmic event. The overlords, rather than bringing battles and struggles to the world, make it a utopia for the human race, but actually their presence initiates the end of humanity. Not only mankind but the entire world is destroyed in drastic chaos. Through the aliens' presence, humans' intelligence is questioned; moreover, religion and science decline. Besides, the aliens turn human children into transhumans and later on they destroy the humans which leads to the destruction of the earth. One might notice that humans should use their reason to handle their life and no extraterrestrial can help them have peace and utopia.

\section{REFERENCES}

[1] Clarke, A. C. (1987).Childhood's End. London: Del Rey.

[2] Childs, P. and Roger Fowler. (2005). The Routledge Dictionary of Literary Terms (Routledge Dictionaries).New York: Routledge Publications.

[3] Daley, T. (2010). Apocalypse Never: Forging the Path to a Nuclear Weapon-Free World. London: Rutgers University Press.

[4] Gammie, J. G. (1974). "Spatial and Ethical Dualism in Jewish Wisdom and Apocalyptic Literature."Journal of Biblical Literature, 93(3), 356-358.

[5] Grossman, J. R. (2011). Keeping the lights on: Post-apocalyptic narrative, social critique, and the cultural politics of emotion.(Order No. 1492388, Colorado State University). ProQuest Dissertations and Theses, 177. Retrieved from: http://search.proquest.com/docview/870390888?accountid=27932. (870390888). (accessed 2/12/2013).

[6] Helm, D. R. (2009). An Approach to Apocalyptic Literature: A Premier for Preachers. Chicago. Chicago: The Charles Simeon Trust Publication.

[7] Joseph, L. E. (2007). Apocalypse 2012: An Investigation into Civilization's End. New York: Morgan Road Books.

[8] Kermode, F. (2000). The Sense of an Ending: Studies in The Theory of Fiction with a New Epilogue. New York: Oxford University Press.

[9] Leigh, D. J. (2008). Apocalyptic Patterns in Twentieth-Century Fiction. Notre Dame: University of Notre Dame Press.

[10] Lewis, S. (2004). M. What Are They Saying about New Testament Apocalyptic? New Jersey: Paulist Press. 
[11] Linton, Gregory L. (2006). "Reading the Apocalypse as Apocalypse: The Limits of Genre." The Reality of Apocalypse: Rhetoric and Politics in the Books of Revelation, ed. David L. Barr. Boston: Brill.

[12] Webb, R. L. (1990). "'Apocalyptic': Observations on a Slippery Term." Journal of Near Eastern Studies, 49(2), 115-126.

[13] Wells, W. (2009). Apocalypse When?: Calculating How Long the Human Race Will Survive . Chichester: Praxis Publishing Ltd.

[14] Wojcik, D. (1997). The End of the World as We Know It: Faith, Fatalism, and Apocalypse in America. New York: New York University Press.

Kamelia Talebian Sedehi was born in Iran in 1987. She received her B.A. (2009) and M.A. (2011) in English Literature from the University of Isfahan. At the present time, she is a $\mathrm{PhD}$ candidate at University Putra Malaysia. Her publications include: The Melancholic Subject and The Bluest Eye, Beloved and Kristevan Melancholic Subject and Natural Selection and The Cage. She has presented at various national and international conferences and is an experienced university lecturer and teacher.

Hardev Kaur PhD is currently a Senior Lecturer attached to University Putra Malaysia. She is the Post-graduate Course Coordinator of English Literature in the English Department. A graduate from the Islamic International University, her doctor al work examined the reconciliation process in post-apartheid South African novels. Her research interests include politics and social issues in novels and trauma theory. She teaches courses on post-nuclear American and British novels. 